\title{
The Essence of Popular Folk Dances of Odisha
}

\author{
Dr.Ashis Mohapatra \\ Guest Faculty, Culture Studies Department, Utkal University of Culture
}

\begin{abstract}
Most Of The Communities Of Odisha Have Their An Folk Cultural Way Of Life Which Includes Folk Dance, Art \& Crafts, Theatre, Songs, Rituals, Legends And Ballades Etc. Odishan Folk Culture Is Still Preserved In Our Rural Life And Agrarian Society. Folk Dances Imbibe New Influences And At The Same Time Maintain Tradition And Continuity. Folk Dances Are Still Popular Among Different Communities Of Odisha. Odishan Folk Culture Is Still Preserved In Our Rural Life And Agrarian Society. Folk Dances Imbibe New Influences And At The Same Time Maintain Tradition And Continuity. Folk Dances Are Simple And Spontaneous. Since There Are No Complex Or Ritual Gestures And Movements, They Can Be Learnt More Easily. Folk Dances Are Passed Down From One Generation To Another, And, Although The Artistes Have A Great Deal Of Liberty In Performance, The Basic Form Remains The Same. Folk Dances Are Performed Singly Or In Groups. Group Dances Are More Common, Reflecting Community Or Collective Thinking. Singing Is An Essential Part Of These Dances. Although The Dancers Themselves Sing At Times, On Other Occasions They Dance To The Singing Of Another Group.
\end{abstract}

Keywords: Culture, Dance, Folk, Odisha, Tradition

The Culture Of Odisha Has Been One Of The Syntheses Of Various Faiths And Cultures. The Cultural Synthesis Of Odisha Is Not Found In Any Other State In The Same Degree As In India. Unlike Other Places, Odishan Culture Is Diverse Because Diversity Several Interactions Formed Different Culture I.E., Tribal Culture, Folk Culture, Food Habit And Religion Etc.. Odisha Has Rich And Hoary Tradition Of Art Stretching Back To Very Ancient Times. Odisha Has A Unique Heritage Of Art-Tradition Beginning From The Sophisticated Ornate Temple Architecture And Sculpture To Folk Arts In Different Forms. Odisha Was Known As 'Utkal' Because Of Her Brilliant Traditions Maintained From Ancient Past In Her Architectural And Sculpture Styles. "Utkal" Means "The Land Of Excellence In Art." Odishan Architecture In A Broad Perspective Can Be Divided Into Rock-Cut Caves And Structural Edifices. By 'Odishan Culture' We Mean The Essential Mental Attributes And Characteristics Peculiarities Which Are Generally Shared By People Of Odisha Irrespective Of Their Religious, Linguistic And Regional Distinction. Different Religions Have Emerged In India As Well As In Odisha At Different Periods Of Time. Being An Ancient Land, Odisha Has Been The Home Of The Dravidians, Aryans And The Tribal People And It Has Acted As Confluence Of Diverse Faiths. The Synthesis Of Different Forms Of Brahminical Worship-Vaishnavite, Shaivite, Shakta, Ganapatya And Soura Is Found Among The People. Religions Have Flourished In The Past In Spite Of The Rise And Fall Of Empires Headed By Rulers Patronizing And Propagating Their Own Faith With Tolerance And Compassion To The Existing Religion.

The Ancient Heritage Of Odisha Has Given Its Cultural Pattern A Broad And Unique Perspective, A Distinctive Character Quite Dissimilar From The Cultural Pattern Of Any Other States. It Is Not Simply The Polished And Trained Conduct And Observance Of Appropriate Social Norms, But A Multifaceted Harmonious Manifestation Of Different Thought, Processes And Ways Of Life Of Our People. Cultural Tolerance Creates The Cultural Pluralism. Cultural Pluralism Is The Social And Political Integration Of People With Different Way Of Living And Thinking Within The Same Society Or Multinational State. Folk Art, Drama, Dance And Songs Etc. have Nourished A Rich Cultural Tradition In Odisha. Though Many Of Them Have Become Extinct And Some Are Languishing, Still There Are Surviving Expressions Preserved And Fostered By The Rural Folk. Each Of The Folk Art Forms Whether Song, Dance Or Drama Presents Numerous Varieties Each Distinctive Because Of Its Character, Occasion, Style And Presentation. There Are Songs Forms The Cradle To The Grave. As Odishan Society Has Been Recognized As An Agrarian Society So, Most Of The Population Still Lives In Villages. From The Cultural View Point Odishan Villages Are Very Important Because They Preserve Odishan Ancient Culture And Folk Cultural Traditions. The Way Of Life Of The Villagers Depends Considerably Upon Natural Forces Due To Their Occupation, Which Is Purely Agrarian In Nature, So They Still Worship Nature. The People Of Villages Still Exhibit Faith In The Doctrine Of Karma, Which Is A Fundamental Principle Of Our Culture And Lead A Simple And Natural Life Dominating By Folk Traditions, Sacrifice, Theistic Tendency And The Importance Of Religion In Every Aspect Of Village Life. Generally In Village Life The Families Fulfill The Needs Of Its Members In All Aspects Of Their Socio-Cultural Life And Exercise Control Over 
Them. It Is Through The Family That The New Members Are Initial Introduced To The Customs, Conventions And Culture Of The Society. Life In A Village Is Self Dependent. Most Of The Villagers Are Farmers And Besides Agricultural Practices The Farmer Is Quite Capable Of Handling The Work Generally Done By The Artisan Class Of People. The Community Of Ideals And Customs As Well As For Social Balance Is Even Today An Important Element Of Odishan Folk Culture. Odishan Folk Dances Are Numerous And Versatile, And They Are Systematized In Multiple Ethnographic Areas Based On Their Correlation, Basic Style, Rhythmical, Spatial And Other Characteristics. The Art Of Folk Dance Is Evolved From The Natural Instinct Of Human Beings Self Expression. Folk Art, Drama, Dance And Songs Etc. have Nourished A Rich Cultural Tradition In Odisha. Though Many Of Them Have Become Extinct And Some Are Languishing, Still There Are Surviving Expressions Preserved And Fostered By The Rural Folk. Each Of The Folk Art Forms Whether Song, Dance Or Drama Presents Numerous Varieties With Distinctive In Nature Because Of Its Character, Occasion, Style And Presentation. There Are Songs Forms The Cradle To The Grave. There Are Dances Beginning From Merry-Making To Martial Activities And There Are Folk Plays Depicting Various Episodes From Mythology, History And Legend, Which Inspire The People And Help To Keep Up Their Morale. Odisha Has The Distinction Of Possessing Rich Folk Culture In All Its Aspects, Spreading In Various Folk Communities From One End To The Other, Communicating To The Mass Its Past Tradition In The Present Day Setting And Shaping Folk Life To Its Tune. Whatever Their Level Of Economical Status, Literacy Rate As Well As Motion Of Progress, Most Of The Communities Of Odisha Have Their An Folk Cultural Way Of Life Which Includes Folk Dance, Art \& Crafts, Theatre, Songs, Rituals, Legends And Ballades Etc. The Phenomena Commonly Called 'Folk Dance' Often Differ Along The Participatory-Presentational Axis. Different Message Receivers And Contexts Of The Communication Process Cause Changes In The Movement Vocabulary And Performing Styles. These Changes Are Especially Remarkable When Traditional Folk Dance Forms In Their Authentic Settings Are Compared To Staged Compositions. With Regular Practice Of Rituals Or Amusement, The Aim Of Folk Dancing Is Physical Exercise, Aesthetic Experience Gained From Displayed Spectacles, And Patriotic Education. The Value Of Folk Dance Is Great, As It Preserves The Tradition And Culture Of The People. Odishan Folk Dances Are A Vessel For The Individual To Express Their Emotions Through Colourful Presentations, Music And Movements. All Performed Movements In Every Dance, Folk Dances Included, Have An Aesthetic Purpose. The Aesthetic Dimension Is One Of The Most Important Ones, Because Dances Represent A Source Of Aesthetic Urges And Feelings. Folk Dances Provide The Possibility For Humans To Aesthetically Shape Themselves, Or Enjoy Other Aesthetic Forms Such As Harmony. The Dance With Its Simple Beauty And Immediateness Is A Medium For Drawing Near Different Clans For Their Better Mutual Acquaintance. The Folk Dance Contributed In Integrating Society As A Unit Cultural Community. As Long As Folk Dances Exist As An Integral Part Of Community Life, They Are Sometimes Linked To Specific Occasions, And May Be Associated With Specific Groups Of People. Most Of Their Folk Dances Are Open To Everyone In The Community. Folk Dances Of Odisha Are Spectacular And A Visual Delight Some Most Popular Folk Dances Of Odisha Are Chaitighoda Nacha Or Dummy Horse Dance, Ghoomra Dance, Baagh Naach Or Tiger Dance, Paika Dance, Ranapa, Danda Nacha, Bharat Lila, Dalkhai Dance, Kathi Nacha(Stick Dance), Medha Nacha(Mask Dance), Sakhi Kandhei Nacha(Puppet Dance), Prahlad Nataka, Patua Dance, Kela Ketuni Dance, Dhap Dance, Jhoomar Dance, Baunsarani Dance, Naga Dance And Ruk Mar Nacha Etc.

Folk Dances Are Still Popular Among Different Communities Of Odisha And Chaiti Ghoda Nacha (Dummy Horse Dance In The Month Of Chaitra) Is One Of Its Vivid Examples. Chaiti Ghoda Nacha Or Dummy Horse Dance Is A Glorious Chapter Of Odishan Folk Culture, Which Is Also Popularly Known As Baseli Or Vasuli Puja. This Horse Dance Is Extremely Simple With Minimum Steps Or Movements Very Easy To Learn And Understand For Which Very Popular Among Local People. People Are Fully Excited While The Dance Performance Along With The People Who Are Witnessing The Dance All Around. The Chaiti Ghoda Nacha (Dummy Horse Dance)As A Part Of Odishan Folk Culture As Well As Popular Culture (Particularly In Villages Of Coastal Odisha) Is Very Popular And Attracts A Large Audience.

'Ghumura' Another Popular Odishan Folk Dance Is Considered As Sign Of Heritage Of Odishan Popular Folk Art. The 'Ghumura' Is A Kind Of Drum Which Produces A Deep Musical Sound. Singers Sing And Dance To The Tune Of Ghumura At Social Functions And Religious Festivals. The Tribal People Of Kalahandi, Koraput, Bolangir And Total Western Odisha Predominantly Perform The Dance. Ghumura Dance It So Unique Form Other Dance And Costume. The Ghumura Dance Has Been Representing The Nation In Various International Events.Popular Folk Dance Chhow Of Odisha Has Evolved Out Of The Extant War Dances Of The Area. Odishan Chhow Has A Large Collection Of Over Hundred Dance Forms. The Traditional Orchestra Of Chhow Consists Of Musicians And Drummers. Ranapa Dance Is A Different Odia Folk Dance Which Is Prevalent In The Cow-Herd Communities. Baagh Naach Is One Another Folk Dance Form Which Is Also Widely Enjoyed By Many People Of Odisha. Moreover This Baagh Naach Is Even Known By Another Name Known As Tiger Dance. The Baunsarani, Literally Meaning 'Bamboo Queen', Is A Very Popular Folk Dance In Coastal Odisha. In This Folk Dance, Little Girls Exhibit Their Acrobatic Movements On A Crossed 
Bamboo Bar As Well As On The Floor With Admirable Accuracy To Entertain The Audience. The 'Dalkhai' Is An Eye-Catching Folk Dance Performance By The Women Dancers In Western Part Of Odisha. This Is MaskDance Most Common During The Religious Processions In The Coastal Districts Of Odisha.Odishan Society Is Undergoing An Acute Culture Crisis; Which Is Reflected By The Traditional Community Organizations Being Suppressed Under Severe Moral, Social And Economic Pressure. Apart From Their Outstanding Brilliance From The Perspective Of Aesthetics, The Folk Dances Of Odisha Have Played An Instrumental Role In Reinforcing National Integrity, Crystallizing Social Solidarity, Fortifying Communal Harmony, Intensifying Value-System And Promoting The Elements Of Humanism Among The People Of The State. Odishan Folk Dances Vividly Depict Life In Its Variegated Colour With Joys And Sorrow, Ups And Downs In Melodious Tunes And Fascinating Ways.Diverse Culture Of Odisha Has The Treasure Of A Variety Of Folk Dances In Sub-Regions Across The State. These Odishan Folk Dances Are Practiced In The Rural Areas And Performed During The Religious Or Seasonal Festivals. Odishan Folk Dance Is Always Accompanied With Folk Song And Folk Musical Instructions. Folk Dances Of Odisha Are Performed By Rural Population To Mitigate Fatigue And Weary. Evolution Of Folk Dance In Odisha Is Intimately Connected With The Growth Of Cultural Life Of The People.Numerous Folk Dances Are In Vogue In Odisha. These Were The Ancient Sources Of Popular Entertainment In The Rural Areas. They Are Closely Associated With Fairs, Festivals And Religious Ceremonies. The State Also Boasts Of A Number Of Folk Dances That Seem To Be A Favorite Amongst The People In Different Districts Of Odisha. Over The Centuries, The State Has Nurtured Distinctive Styles Of Folk Art Forms. Music And Dance Is Integral To The Lives Of The People Of The State. Folk Art Is Deeply Connected To The Community. They Emerge From The Daily Life Of A Community And Are Shaped By The Environment In Which The Community Lives. Folk Art Is Motivated By Utilitarian And Ritualistic Features And Sometimes By Recreational Impulses. Some Practitioners Maybe Better Skilled Than Others, But Folk Arts Are Essentially About A Group Or Community Rather Than The Individual Artist. Mainly Dominated And Shaped By Religious Motifs, The Relation Between This Art And Religion Is A Universal Feature. It Is An Integral Part Of Living. Folk Art Has An Important Role In Handing Down Social Norms And Religious Knowledge And Wisdom And In Keeping The Social Structure Stable. The Folk Art, Music And Dance Vary From Region To Region. Apart From Creating Cultural Identity, Fork-Art Forms Have Other Great Social Missions. The Most Important Is The Collective Conscience They Produce. The Integrity Of Individuals And Equipping Them To Meet Social Challenges Are A Part Of This. Folk Dances Belong To The Villages And Are Generally Associated With The Agriculture.

Many Of The Odishan Folk Dances Are Related To Harvest And Religious And The Ancient Gods And Goddesses Associated With Them. The Early Odishan Folk Dances, Like Other Forms Of Primitive Art, Were Essentially Ritual Enactments Of Superstitious Beliefs Performed In The Hope Of A Good Harvest. Most Of The Folk Dances That Were Developed During Ancient Period Reflected A Superstitious Belief That In Making Ritual Sacrifices To The Gods In Appreciation Of The "Harvest", One Could Persuade The Gods To Provide Another Bountiful Harvest In The Following Year. Odishan Folk Dances Reflect The Peculiarities Of Particular Community's Religious, Cultural And Historical Narrative, As It Were; The Dances, Their Choreography And Their Colorful Costumes Naturally Reflect Their Unique Narrative. While The Heritage Of The Folk Dance That Was Passed Down The Generations Among Ethnic Groups As A Whole Was Rich And Varied, It Was Unevenly Distributed From Group To Group, Partly Because Whole Chapters, As It Were, Of The Tradition Had Been Lost, For Various Reasons, Often Owing To The Upheavals Of War And The Struggle For Survival In The Face Of Seemingly Insurmountable Odds. The Richness Of The Original Odishan Folk Dance, In All Its Aspects Both In Terms Of Choreography And Repertoire As Well As In Terms Of The Exact Replication Of The Original Costumes Has Slowly Made A Comeback, And Today Is Recognized. Odishan Folk Dances Are Of Course More Than Simple Vehicles Of Ethnic Expression; They Are Sometimes Highly Sophisticated And Elaborate Even Dazzlingly Spectacular Displays Of Dance And Pageantry, Sometimes With A Martial Arts Theme, Choreographed To Celebrate Official Ceremonies.

Folk Grooving Is Surely An Expression Of Delight, Some Sort Of Party Of Lifetimes; It Is Magnificence In Addition To Colour. In Many Cases Folk Dances Of Odisha Are Celebratory In Addition To In Season Throughout Dynamics. As An Example, They're Employed To Commemorate Births, Marriages, Celebrations In Addition To Spiritual Activities. They Have Got Various Variations, Costumes In Addition To Rates. Folk Dances Are Passed Down From One Generation To Another, And, Although The Artistes Have A Great Deal Of Liberty In Performing, The Basic Form Remains The Same As A Matter Of Tradition. Some Folk Dances Are Influenced By Religious Beliefs And Stories; Others Are Inspired By Local Myths And Legends. Such Dances Attract Participants And Audiences Mainly From Their Respective Communities. However, Some Folk Dances Have Universal Appeal. Folk Dance Is The Dance Of Primitive Or Rural Communities Originating From Their Culture And Closely Reflecting Their Way Of Life. In Odisha, Folk Dances Have Flourished Since Ancient Times. Folk Dances Are Made Up Of Many Parallel And Successive Elements, Which Have Been Combined And Transformed By The People. Every Folk Dance Is Rooted In A Particular Region, And Is 
Accordingly Treasured By Its Inhabitants As A Part Of Local, Rather Than National, Culture. Odishan Folk Dance Always Connects To The Ethos Of The Land. Folk Dances Are About History; About Traditions And Exotic Beauty Of The Land It Is Associated With. Some Dances Reflect Natural Events Or Daily Life, And Others Treat Social Events And Matters Of The Heart. Thus, Odishan Folk Dance Refers To The Dance Of The Common People Which Spontaneously Emerged And Developed Among Ethnic Groups And Communities, Reflective Of The Characteristics Of Particular Regions, And Representing The Group's Sentiments And Emotions. Folk Dances Of Odisha Are A Unique Performance Genre That Has The Ability To Display And, In Many Cases, Transform Folk Elements As A Basis For Representation, Commentary, And Reflection. Especially In Villages, It Has Its Own Collective Living Which Is Bounded By Certain Common Socio Cultural Norms. Folk Dances Represent The Soul Of Odishan Agrarian Society. As A Folk Art Form, Characterized By Originality And Complexity, Folk Dances Are A Manifestation Of A Society Or Community's Will. Through Folk Dances, The People Of Agrarian Society Could Express Their Feelings Of Happiness Or Sadness And They Could Reinforce Their Individuality In Connection With Other Societies. Odisha Has Been A Rich Store House Of Numerous Folk Dances Or Performing Folk Arts, Over The Centuries, Which Can Rightly Be Regarded As Her Glorious And Everlasting Cultural Heritage, Attracting Universal Attention And Appreciation Within The State And Abroad In Its Multi- Dimensional Cultural Forms And Expressions Ornamented With Qualities Of Both Head And Heart, In Most Meaningful And Conceivable Ways, Manners And Styles. Folk Dances Of Odisha Do Illustrate A Message By Means Of Which They Declare Themselves As Part Of The Cultural History Of This Land. They Are Able To Reveal The People's Cultural Practices, Feelings And Wishes In A Sincere, Direct Manner, They Are Closely Related To The Life And History Of Different Communities, They Faithfully Accompany People In Happiness Or Sadness; Thus They Succeed In To Equally Expressing The Cultural Elements, Temperament, Force, Wit And Wisdom, As Well As The Sense Of humour that A Nation Exhibits. In Odisha Generally Folk Dancing Is A Form Of Folk Art Which Originates As A Cultural Expression From People Around The State At The Level Of The Village. With Colorful Costumes And Vibrant Figures, Folk Dances In Odisha Are Not Only The Most Important Components Of People's Entertainment Culture, But Also Carry Thousands Years Old Cultural Motifs To The Future And Assume An Important Role In Preserving A Heritage. Despite The Changing Political And Social Climate, In Some Circles In Odisha, Folkdance Continues To Blossom And Enjoy Popularity.

\section{REFERENCES}

[1] Das,Binod. S. (Ed) : Glimpses Of Orissa. Calcutta, 1986.Jena,B. B. : Orissa-People, Culture And Polity, New Delhi, 1981.

[2] Kalahandi: Loka Anusthan, Edited By Jayanta Kumar Behera, Dr Dolagobinda Bisi, ParameswarMund, Mahabir Sanskrutika Anusthan, 1998.

[3] Loka Nutrya Ghumura, Edited By Parameswar Mund, Mahabir Sanskrutika Anusthan, June- 2002.5. ahapatra,Bhagyalaxmi : Ethnic Dances And Music Of Western Orissa: An Anthropological Study, Towards Promoting Eco-Tourism Publishing Company, 2011.6. Mishra,Mahendra Kumar : Oral Epics Of Kalahandi , Nfsc; 1st Edition ,2014.

[4] Mohapatra ,Shyam Sundar :Folklore Studies In Orissa, Lokaratna. Vol.1, 2008.8. Pal ,Animeshkanti Lokosanskriti,Prognavikash, Kolkata, 2009.

[5] Pasayat,C. (Ed.): Paschima Odishara Lokageeta, Folklore Foundation, Bhubaneswar, 2008.10. Patnaik ,Nihar. R. (Ed): Glimpses Of Orissan Culture, Kitab Mahal, Cuttack, 2004.

[6] Singh Deo,J. P. : Cultural Profile Of South Kosala. Gian Publishing.New Delhi.1987.12. Upadhayaya, K.D.: "Society As Depicted In Indian Folk-Narratives", Fabula. Volume 9, Issue 1-3,September, 2009. 